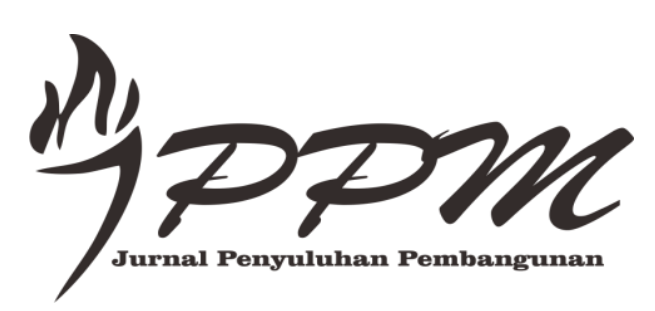

http://jurnal.polbangtanmalang.ac.id/index.php/jppm

Jurnal Penyuluhan Pembangunan Volume 1, Nomor 1 Tahun 2019

\title{
Adopsi Inovasi Pemanfaatan Kotoran Ternak Sapi Untuk Pembuatan Pupuk Bokashi di Kelompoktani "Usaha Bersama" Desa Sekarmojo Kecamatan Purwosari Kabupaten Pasuruan
}

\author{
Adoption of Cow Manure Utilization Innovations for \\ Making Bokashi Fertilizers in Farmers' Groups 'Joint \\ Ventures" Sekarmojo Village, Purwosari District, \\ Pasuruan Regency
}

\author{
Abdul Farid, IGN, Mudita, Tri Pudjianto \\ Program Studi Penyuluhan Pertanian Berkelanjutan, Polbangtan Malang \\ e-mail: abdul.farid@polbangtanmalang.ac.id
}

\begin{abstract}
Abstrak
Pemanfaatan kotoran ternak sapi belum optimal, petani lebih tergantung pada pupuk anorganik. Selain itu masalah yang dihadapi petani saat ini yaitu kelangkaan pupuk. Untuk mengatasi hal tersebut, salah satu potensi yang bisa dimanfaatkan yaitu pembuatan pupuk bokashi dari kotoran ternak sapi. Fungsi pupuk bokashi antara lain meningkatkan kesuburan tanah, pertumbuhan dan produksi tanaman, pembuatan mudah, biaya murah dan bahan mudah diperoleh. Tujuan penelitian ini adalah: 1) untuk mengetahui tingkat adopsi inovasi petani terhadap pemanfaatan kotoran ternak sapi untuk pembuatan pupuk bokashi, 2) untuk mengetahui pengaruh karakteristik petani (umur, tingkat pendidikan, luas usahatani dan pengalaman berusahatani) terhadap adopsi teknologi pemanfaatan kotoran ternak sapi untuk pembuatan pupuk bokashi, 3) untuk menyusun rancangan penyuluhan yang tepat tentang pemanfaatan kotoran ternak sapi untuk pembuatan pupuk bokashi. Hasil penelitian menunjukkan bahwa tingkat adopsi petani di Desa Sekarmojo masih rendah, dari 30 responden hanya ada 4 responden yang sudah menerapkan adopsi. Dengan taraf signifikan $(\alpha) 0,05$, umur berpengaruh yang signifikan terhadap adopsi pemanfaatan kotoran ternak sapi untuk pembuatan pupuk bokashi dengan nilai signifikansi 0,008, namun mempunyai arah ramalan negatif. Tingkat pendidikan berpengaruh positif yang signifikan terhadap tingkat adopsi dengan nilai signifikansi 0,004. Luas usahatani tidak berpengaruh signifikan terhadap tingkat adopsi dengan nilai signifikansi 0,509. Sedangkan pengalaman berusahatani berpengaruh yang signifikan terhadap tingkat adopsi pemanfaatan kotoran ternak sapi untuk pembuatan pupuk bokashi dengan nilai signifikansi 0,000 namun mempunyai arah ramalan negatif. Penyuluhan tentang pemanfaatan kotoran ternak sapi untuk pembuatan pupuk bokashi menggunakan metode dan teknik ceramah, diskusi, demonstrasi cara. Media yang digunakan folder dan benda sesungguhnya.
\end{abstract}

Kata kunci: Penyuluhan, adopsi, kotoran ternak sapi, bokashi 
Abdul Farid, IGN, Mudita, Tri Pudjianto, Adopsi Inovasi Pemanfaatan Kotoran Ternak Sapi Untuk Pembuatan Pupuk Bokashi di Kelompoktani "Usaha Bersama” Desa Sekarmojo Kecamatan Purwosari Kabupaten Pasuruan

\begin{abstract}
Utilization of organic materials is not optimal, farmers more dependent on inorganic fertilizers. In addition to the problems faced by farmers today is the scarcity of fertilizers. To overcome this, one of the potential that can be exploited is bokashi fertilizer from cow manure. The function of bokashi fertilizer is to improve soil fertility, plant growth and production, the manufacture of simple, low cost and material available many around us. The purpose of this study is: 1) to determine the level of adoption of innovation by farmers to use cow manure for fertilizer bokashi, 2) to determine the effect of farmers' characteristics (age, education level, extensive farming and farming experience) to the adoption of technology utilization for cattle dung bokashi fertilizer, 3) to draft the proper counseling about the use of cow manure for fertilizer bokashi. The results showed that the adoption rate of farmers in the village Sekarmojo still low, of 30 respondents only 4 respondents who have applied adoption. With significance level $(\alpha)$ of 0.05, a significant effect of age on the utilization of the adoption of cow manure for fertilizer bokashi with a significance value of 0.008, but has a negative forecast direction. The level of education is a significant positive effect on the level of adoption with a significance value of 0.004. Area of farming does not significantly influence the level of adoption with a significance value of 0.509. While farming experience significant effect on the adoption rate of cattle manure utilization to bokashi fertilizer with a significance value of 0.000 but has forecast negative direction. Guidance on the use of cow manure for fertilizer bokashi using methods and techniques of lecture, discussion, demonstration ways. Media used folders and real objects.
\end{abstract}

Keywords: extension, adoption, cow manure, bokashi

\title{
I. PENDAHULUAN
}

Saat ini telah terjadi kerusakan lahan pertanian yang disebabkan beberapa faktor, salah satunya adalah penggunaan pupuk kimia secara berlebihan (over dosis) dari rekomendasi pemerintah. Disamping itu petani belum memanfaatkan sisa hasil panen padi dan limbah kotoran ternak. Selama ini sisa hasil panen seperti jerami padi yang seharusnya dikembalikan ke dalam tanah sebagai pupuk organik justru dibakar dan digunakan untuk kepentingan lain. Desa Sekarmojo adalah salah satu desa di Kecamatan Purwosari Kabupaten Pasuruan yang memiliki populasi sapi cukup banyak. Berdasarkan data hasil Sensus Pertanian Tahun 2013, jumlah ternak sapi di Desa Sekarmojo tercatat 1.138 ekor atau $14,03 \%$ dari total populasi ternak sapi di Kecamatan Purwosari yang berjumlah 8.111 ekor. Apabila per ekor sapi menghasilkan kotoran sabanyak $15 \mathrm{~kg} / \mathrm{hari}$, maka potensi kotoran ternak sapi yang dihasilkan di Desa Sekarmojo sekitar 17,07 ton/hari, sehingga sangat berpotensi untuk dimanfaatkan sebagai pupuk bokashi. Namun penanganan kotoran ternak sapi masih terbatas, sehingga menyebabkan terjadinya penumpukan feaces dan sisa-sisa pakan yang bercampur urin, akibatnya akan terjadi pencemaran lingkungan. Untuk mencegah terjadinya pencemaran lingkungan, seharusnya kotoran ternak sapi dapat digunakan sebagai bahan pembuatan pupuk organik. Adanya berbagai macam inovasi pembuatan pupuk organik merupakan alternatif pemecahan masalah yang sangat tepat salah satunya melalui Penyuluhan Adopsi Inovasi Pemanfaatan Kotoran Ternak Sapi untuk Pembuatan Pupuk Bokashi. 
Abdul Farid, IGN, Mudita, Tri Pudjianto, Adopsi Inovasi Pemanfaatan Kotoran Ternak Sapi Untuk Pembuatan Pupuk Bokashi di Kelompoktani "Usaha Bersama” Desa Sekarmojo Kecamatan Purwosari Kabupaten Pasuruan

Tujuan dari penelitian ini adalah sebagai berikut: 1) Untuk mengetahui tingkat adopsi petani terhadap teknologi pemanfaatan kotoran ternak sapi untuk pembuatan pupuk bokashi, 2) Untuk mengetahui pengaruh karakteristik petani (umur, tingkat pendidikan, luas usahatani dan pengalaman berusahatani) terhadap adopsi teknologi pemanfaatan kotoran ternak sapi untuk pembuatan pupuk bokashi, 3) Untuk menyusun rancangan penyuluhan yang tepat tentang pemanfaatan kotoran ternak sapi untuk pembuatan pupuk bokashi

\section{METODE PENELITIAN}

Kegiatan kajian dilaksanakan di Kelompoktani Usaha Bersama Desa Sekarmojo Kecamatan Purwosari Kabupaten Pasuruan Provinsi Jawa Timur pada tanggal 5 Mei sampai 16 Juni 2014, dan penyuluhan dilaksanakan pada tanggal 19 Juni 2014.

Dalam penyusunan rancangan kajian, pendekatan yang digunakan adalah kajian pustaka dan survei tingkat adopsi inovasi petani terhadap pemanfaatan kotoran ternak sapi untuk pembuatan pupuk bokashi dengan menggunakan kuisioner. Wawancara kepada anggota Kelompoktani Usaha Bersama dilakukan dengan menggunakan daftar pertanyaan yang telah dipersiapkan sebelumnya untuk mengetahui tingkat pengetahuan dasar responden, serta penulis melihat secara langsung kotoran ternak sapi yang belum dimanfaatkannya. Data hasil survei, wawancara dan observasi yang telah dilakukan pada responden dikumpulkan untuk kemudian dianalisis sebagai dasar dalam penyusunan rancangan penyuluhan kepada petani yang ada di Kelompoktani Usaha Bersama.

Teknik pengambilan sampel dalam kajian ini dilakukan dengan cara purposive sampling, yaitu pengambilan sampel secara sengaja berdasarkan tujuan kajian (Riduwan, 2012). Adapun variabel bebas yang diamati adalah umur petani, tingkat pendidikan, luas usaha tani, dan lama berusaha tani. Sedangkan variabel terikatnya adalah adopsi petani tentang pemanfaatan kotoran sapi untuk pembuatan pupuk bokashi.

Untuk mengetahui tingkat adopsi Kelompoktani Usaha Bersama tentang pemanfaatan kotoran sapi untuk pembuatan pupuk bokashi, maka dilakukan analisis data dengan menggunakan tabulasi sederhana dari hasil wawancara yang menggunakan kuisioner dalam bentuk pertanyaan-pertanyaan yang berkaitan dengan adopsi pemanfaatan kotoran sapi untuk pembuatan pupuk bokashi. Pertanyaan dibuat sebanyak 30 nomor dengan skor nilai 5 untuk jawaban yang paling benar, nilai 3 untuk jawaban benar dan nilai 1 untuk jawaban kurang benar. Jumlah skor maksimal dari seluruh pertanyaan adalah 150 sedangkan nilai terendah adalah 30 .

Untuk mempermudah dalam menganalisis data maka dibuat klasifikasi berdasarkan 5 (lima) kategori sebagai berikut:

1. Kategori sangat kurang, maka tingkat adopsi yang dimiliki petani pada tahap sadar.

2. Kategori kurang, maka tingkat adopsi petani pada tahap minat

3. Kategori sedang, maka tingkat adopsi petani pada tahap menilai.

4. Kategori baik, maka tingkat adopsi petani pada tahap mencoba.

5. Kategori sangat baik, maka tingkat adopsi petani pada tahap menerapkan.

Dengan demikian interpretasi dari kategori ini sebagai berikut:

1. Kategori sangat kurang: $30-53$

2. Kategori kurang: $54-77$

3. Kategori sedang : $78-101$

4. Kategori baik: $102-125$

5. Kategori sangat baik: $126-150$ 
Abdul Farid, IGN, Mudita, Tri Pudjianto, Adopsi Inovasi Pemanfaatan Kotoran Ternak Sapi Untuk Pembuatan Pupuk Bokashi di Kelompoktani "Usaha Bersama” Desa Sekarmojo Kecamatan Purwosari Kabupaten Pasuruan

Untuk mengetahui faktor-faktor yang mempengaruhi tingkat adopsi inovasi pemanfaatan kotoran ternak sapi untuk pembuatan pupuk bokashi digunakan analisis regresi sederhana dengan menggunakan persamaan sebagai berikut:

$$
\hat{\mathrm{Y}}=\mathrm{a}+\mathrm{bX}
$$

Keterangan :

$\hat{Y}=$ Subyek variabel terikat yang diproyeksikan

$\mathrm{X}=$ Variabel bebas yang mempunyai nilai

tertentu untuk diprediksikan

a = Nilai konstanta harga $\mathrm{Y}$ jika $\mathrm{X}=0$

$\mathrm{b}=$ Nilai arah sebagai penentu ramalan (prediksi) yang menunjukkan nilai peningkatan (+) atau nilai penurunan (-) variabel Y.

\section{Rancangan Penyuluhan}

Sasaran penyuluhan adalah Kelompoktani Usaha Bersama Desa Sekarmojo Kecamatan Purwosari Kabupaten Pasuruan yang ditetapkan sebagai sampel kajian. Materi yang disuluhkan adalah pembuatan pupuk bokashi dari kotoran sapi yang belum diketahui oleh petani sasaran. Penyuluhan dilaksanakan dengan pendekatan kelompok dan perorangan dengan metode ceramah, demonstrasi cara dan diskusi. Media penyuluhan yang digunakan adalah folder yang berisi tentang petunjuk kerja yang mudah dipahami dan mudah dilakukan oleh petani. Persiapan penyuluhan dilakukan dengan menyiapkan Lembar Persiapan Menyuluh (LPM) supaya penyuluhan dapat sistematis dan efisien. Setelah dilakukan penyuluhan perlu dilakukan perhitungan hasil antara pre test dan pos test untuk mengetahui tingkat efektifitas peningkatan pengetahuan dengan menggunakan rumus (Ginting,2004): Efektifitas Peningkatan Pengetahuan

$$
=\frac{\operatorname{Ps}-\operatorname{Pr}}{(\text { N.5.Q) }-\operatorname{Pr}} \times 100 \%
$$

Efektifitas Program $=\frac{P s}{N 5 Q} \times 100 \%$

Keterangan :

$$
\begin{aligned}
& \mathrm{Ps}=\text { Pos tes } \\
& \mathrm{Pr}=\text { Pre tes } \\
& \mathrm{N}=\text { Jumlah responden } \\
& 5=\text { Nilai jawaban benar } \\
& \mathrm{Q}=\text { Jumlah pertanyaan }
\end{aligned}
$$

Maka kriteria persentase efektifitas tingkat pengetahuan yaitu:
1. Efektif $>66,66 \%$
2. Cukup efektif $=33,33 \%-66,66 \%$
3. Kurang efektif $<33,33 \%$

\section{HASIL DAN PEMBAHASAN}

\section{Keadaan Responden Berdasarkan Umur}

Umur adalah usia responden yang dihitung sejak lahir sampai penelitian dilakukan yang dinyatakan dalam satuan tahun. Adapun jumlah responden berdasarkan umur disajikan pada Tabel 1. 
Abdul Farid, IGN, Mudita, Tri Pudjianto, Adopsi Inovasi Pemanfaatan Kotoran Ternak Sapi Untuk Pembuatan Pupuk Bokashi di Kelompoktani "Usaha Bersama” Desa Sekarmojo Kecamatan Purwosari Kabupaten Pasuruan

Tabel 1. Jumlah Responden Berdasarkan Umur

\begin{tabular}{llccc}
\hline \multirow{2}{*}{ NoKategori Umur } & Kriteria (tahun) & Jumlah (Orang) & Persentase (\%) \\
\hline 1 & Muda & $26-36$ & 8 & 26,67 \\
2 & Sedang & $37-47$ & 10 & 33,33 \\
3 & Tua & $48-59$ & 12 & 40 \\
\hline & Jumlah & 30 & 100 \\
\hline
\end{tabular}

Sumber: Data terolah Tahun 2014

Tabel 1 menjelaskan bahwa responden yang memiliki kategori umur tua memiliki jumlah responden yang paling banyak yaitu 12 orang (40\%), diikuti responden berumur sedang dengan jumlah 10 orang $(33,33 \%)$ dan paling sedikit responden berumur muda dengan jumlah 8 orang $(26,67 \%)$. Hal ini berarti bahwa mayoritas petani di kelompktani ini masih didominasi oleh petani dengan kategori umur tua dan sedang. Hasil wawancara dengan penduduk diperoleh informasi bahwa penduduk yang berusia muda memiliki kecenderungan untuk melakukan pekerjaan di luar sektor pertanian atau peternakan. Berdasarkan pengamatan di lokasi kajian, diduga penduduk yang berumur muda lebih tertarik bekerja di pabrik-pabrik yang ada di sekitar desa.

\section{Keadaan Responden Berdasarkan Tingkat Pendidikan}

Tingkat Pendidikan adalah jenjang pendidikan formal yang pernah diikuti oleh petani. Hasil wawancara dengan responden diperoleh tingkat pendidikan responden dari SD sampai SMA. Jumlah responden berdasarkan tingkat pendidikan disajikan pada Tabel 2.

Tabel 2. Jumlah Responden Berdasarkan Tingkat Pendidikan

\begin{tabular}{clcc}
\hline No & Kelompok Pendidikan & Jumlah (Orang) & Persentase (\%) \\
\hline 1 & SD & 13 & 43,33 \\
2 & SMP/SLTP & 10 & 33,33 \\
3 & SMA/SLTA & 7 & 23,33 \\
\hline & Jumlah & 30 & 100 \\
\hline
\end{tabular}

Sumber: Data terolah Tahun 2014

Tabel 2 menjelaskan bahwa responden terbanyak pada kelompok pendidikan SD dengan jumlah 13 orang (43,33\%). Kelompok pendidikan SMP/SLTP dengan jumlah responden 10 orang ( $33,33 \%)$, kemudian kelompok pendidikan SMA/SLTA dengan jumlah responden sebanyak 7 orang $(23,33 \%)$. Dari Tabel 10 dapat dinyatakan bahwa sebagian besar responden mempunyai tingkat pendidikan SD. Dari kondisi tersebut dapat disimpulkan bahwa responden memiliki ilmu pengetahuan yang terbatas melalui pendidikan formal, sehingga perlu informasi tambahan melalui pendidikan non formal. Salah satu pendidikan non formal yang bisa dilakukan adalah melalui penyuluhan.

\section{Keadaan Responden Berdasarkan Luas Usahatani}


Abdul Farid, IGN, Mudita, Tri Pudjianto, Adopsi Inovasi Pemanfaatan Kotoran Ternak Sapi Untuk Pembuatan Pupuk Bokashi di Kelompoktani "Usaha Bersama” Desa Sekarmojo Kecamatan Purwosari Kabupaten Pasuruan

Luas usaha tani yang dimiliki oleh responden bervariasi dari kepemilikan lahan yang sempit mulai 0,07 ha sampai kepemilikan lahan yang luas yaitu 1,3 ha. Jumlah responden berdasarkan luas usahatani disajikan dalam Tabel 3.

Tabel 3. Jumlah Responden Berdasarkan Luas UsahaTani

\begin{tabular}{clccc}
\hline \multirow{2}{*}{ No } & Kategori & Luas Lahan (ha) & Jumlah (Org) & Persentase (\%) \\
\hline 1 & Sempit & $0,07-0,47$ & 21 & 70,00 \\
2 & Sedang & $0,48-0,88$ & 5 & 16,67 \\
3 & Luas & $0,89-1,30$ & 4 & 13,33 \\
\hline \multicolumn{7}{r}{ Jumlah } & 30 & 100 \\
\hline
\end{tabular}

Sumber: Data terolah Tahun 2014

Tabel 3 menjelaskan bahwa sebagian besar (70,\%), responden memiliki lahan yang sempit yaitu antara $0,07-0,47$ ha, responden yang memiliki lahan sedang $30 \%$ dan hanya $10 \%$ responden yang memiliki lahan luas. Dengan kepemilikan lahan usaha tani yang sempit diharapkan petani dapat mengelola lahan pertanian mereka secara intensif, salah satunya adalah dengan penggunaan bahan-bahan organik seperti pupuk bokashi untuk mempertahankan kesuburan tanah.

\section{Keadaan Responden Berdasarkan Pengalaman Berusaha tani}

Dari hasil wawancara dengan responden diperoleh data bahwa pengalaman bertani paling rendah (baru) adalah 4 tahun dan paling lama adalah 36 tahun. Jumlah responden berdasarkan pengalaman menjadi petani atau pengalaman berusaha tani disajikan pada Tabel 4

Tabel 4. Jumlah Responden Berdasarkan Pengalaman Berusaha tani

\begin{tabular}{clccc}
\hline No & Kategori & $\begin{array}{c}\text { Pengalaman berusahatani } \\
\text { (tahun) }\end{array}$ & Jumlah (Orang) & Persentase (\%) \\
\hline 1 & Baru & $4-14$ & 7 & 23,33 \\
2 & Sedang & $15-25$ & 11 & 33,67 \\
3 & Lama & $26-36$ & 12 & 40,00 \\
\hline \multicolumn{5}{r}{} \\
\hline
\end{tabular}

Sumber: Data terolah Tahun 2014

Tabel 4 menjelaskan bahwa sebagian besar responden termasuk petani yang mempunyai pengalaman berusaha tani dalam kategori lama yaitu 12 responden, diikuti responden dengan pengalaman berusaha tani sedang dengan jumlah 11 orang, diduga pengalaman responden yang lebih lama akan mempermudah dalam menerima inovasi baru. Seperti pendapat Mosher (1977) dalam Kusumahadi (1989) yang menyatakan bahwa lama usaha adalah pengalaman berharga yang dapat diambil manfaatnya sehingga dapat membantu petani dalam mengembangkan usaha taninya.

\section{Tingkat Adopsi Anggota Kelompoktani Usaha Bersama Terhadap Pemanfaatan Kotoran Ternak Sapi untuk Pembuatan Pupuk Bokashi}

Distribusi tingkat adopsi tentang pemanfaatan kotoran ternak sapi untuk pembuatan pupuk bokashi pada anggota Kelompoktani Usaha Bersama di Desa 
Abdul Farid, IGN, Mudita, Tri Pudjianto, Adopsi Inovasi Pemanfaatan Kotoran Ternak Sapi Untuk Pembuatan Pupuk Bokashi di Kelompoktani "Usaha Bersama” Desa Sekarmojo Kecamatan Purwosari Kabupaten Pasuruan

Sekarmojo yang diperoleh dari hasil wawancara didasarkan beberapa karakteristik responden yaitu:

\section{Umur Responden}

Petani responden di Kelompoktani Usaha Bersama memiliki umur beragam. Distribusi tingkat adopsi berdasarkan umur Kelompoktani Usaha Bersama terhadap pemanfaatan kotoran ternak sapi untuk pembuatan pupuk bokashi disajikan pada Tabel 5.

Tabel 5. Distribusi Tingkat Adopsi Pemanfaatan Kotoran Ternak Sapi untuk Pembuatan Pupuk Bokashi Didasarkan Pada Umur Responden

\begin{tabular}{ccccccccc}
\hline & & \multicolumn{9}{c}{ Tingkat Adopsi } & Skor & $\begin{array}{c}\text { Rata- } \\
\text { rata }\end{array}$ \\
\cline { 3 - 8 } & Kategori & Sadar & Minat & Evaluasi & Mencoba & Menerapkan & $\begin{array}{c}\text { Adopsi } \\
\text { Adopsi }\end{array}$ \\
\hline $26-36$ & Muda & - & - & 2 & 5 & 1 & 902 & 112,75 \\
$37-47$ & Sedang & - & 1 & 2 & 5 & 2 & 1112 & 111,2 \\
$48-59$ & Tua & 1 & 1 & 7 & 2 & 1 & 1143 & 95,25 \\
\hline Jumla & & 1 & 2 & 10 & 13 & 4 & 30 & \\
\hline
\end{tabular}

Sumber: Data terolah Tahun 2014

Tabel 5 menjelaskan bahwa rata-rata tingkat adopsi paling tinggi dicapai pada responden umur muda yaitu 112,75 diikuti responden dengan umur sedang 111,2 dan responden umur tua 95,25. Semakin muda petani biasanya cepat tanggap dan mudah menerima hal-hal yang baru. Hal ini sesuai dengan pendapat Soekartawi (2005) yang menyatakan makin muda petani biasanya mempunyai semangat untuk ingin tahu apa yang belum diketahui, sehingga dengan demikian mereka berusaha untuk lebih cepat melakukan adopsi inovasi walaupun sebenarnya mereka masih belum berpengalaman soal adopsi inovasi tersebut. Responden yang lebih tua cenderung kurang dalam melakukan adopsi. Walaupun beberapa bukti menunjukkan bahwa petani-petani relatif lebih tua kurang menerima perubahan daripada yang muda, namun bukan berarti mereka tidak menerima perubahan untuk orang lain..

Analisis statistik menggunakan statistic program for social sciences (SPSS) dengan analisis regresi linier sederhana dan dalam analisis statistik ini diasumsikan variabel yang lain tidak berpengaruh terhadap adopsi, diperoleh nilai konstanta (a) 145,683 dan nilai arah sebagai penentu ramalan (b) - 0,919, sehingga diperoleh persamaan regresi $\hat{Y}=145,683+(-0,919) X$. Karena nilai koefisien $(b)=-0,932$ (negatif) maka model regresi bernilai negatif, artinya jika nilai variabel umuri (X) semakin tinggi maka nilai variabel tingkat adopsi (Y) semakin rendah. Hal ini disebabkan karena petani yang lebih tua cenderung kurang tanggap terhadap adanya halhal baru. Walaupun beberapa bukti menunjukkan bahwa petani-petani relatif lebih tua kurang menerima perubahan daripada yang muda, namun bukan berarti mereka tidak menerima suatu perubahan. Pertimbangan-pertimbangan lain adalah kesehatan dan sifat yang statis. Hal ini sesuai dengan pendapat Mardikanto (1993) yang menyatakan bahwa semakin tua umur seseorang maka semakin lambat dalam mengadopsi inovasi dan cenderung hanya melaksanakan kegiatan-kegiatan yang sudah biasa diterapkan oleh masyarakat setempat.

Untuk melihat ada atau tidak ada pengaruh dapat dilihat pada nilai $P$ value Sig adalah 0,008 artinya karena nilai $P$ value Sig. kurang dari 0,05 maka dapat disimpulkan "terdapat pengaruh yang signifikan antara umur (X) dengan tingkat adopsi (Y)", dan nilai 
Abdul Farid, IGN, Mudita, Tri Pudjianto, Adopsi Inovasi Pemanfaatan Kotoran Ternak Sapi Untuk Pembuatan Pupuk Bokashi di Kelompoktani "Usaha Bersama” Desa Sekarmojo Kecamatan Purwosari Kabupaten Pasuruan

koefisien korelasi adalah $\mathrm{R}=0,477$. Yang artinya hubungan antara umur $(\mathrm{X})$ dengan tingkat adopsi (Y) sedang. Koefisien Penentu (KP) atau ada yang menyebutnya koefisien Determinasi yang dirumuskan $\mathrm{KP}=\mathrm{R}^{2} \times 100 \%=(0,477)^{2} \times 100 \%$ diperoleh nilai $22,7 \%$ artinya tingkat adopsi dipengaruhi oleh umur sebesar $22,7 \%$ sedangkan sisanya dipengaruhi oleh faktor lain.

\section{Tingkat Pendidikan}

Tingkat pendidikan adalah lama pendidikan responden yang telah dilalui di bangku sekolah formal yang dikelompokkan dalam tiga kategori, yaitu SD/sederajat, SLTP/sederajat dan SMA/sederajat. Untuk mempermudah pengolahan data dengan SPSS maka masing-masing kategori diberi skor yaitu pendidikan SD/sederajat dengan skor 6 , SLTP/sederajat skor 9 dan pendidikan SMA/sederajat diberi skor 12.

Distribusi tingkat adopsi anggota kelompoktani terhadap pemanfaatan kotoran ternak sapi untuk pembuatan pupuk bokashi didasarkan pada tingkat pendidikan responden disajikan pada Tabel 6.

Tabel 6. Distribusi Tingkat Adopsi Pemanfaatan Kotoran Ternak Sapi untuk Pembuatan Pupuk Bokashi Didasarkan pada Tingkat Pendidikan

\begin{tabular}{lcccccccc}
\hline \multirow{2}{*}{$\begin{array}{c}\text { Tingkat } \\
\text { Pendidikan }\end{array}$} & Sadar & Minat & Evaluasi & Mencoba & Menerapkan & $\begin{array}{c}\text { Skor } \\
\text { Adopsi }\end{array}$ & $\begin{array}{c}\text { Rata- } \\
\text { rata } \\
\text { Adopsi }\end{array}$ \\
\hline SD/MI & 1 & 2 & 6 & 3 & 1 & 1239 & 95,31 \\
SMP/MTs & - & - & 2 & 7 & 1 & 1124 & 112,4 \\
SMA/STM & - & - & 1 & 4 & 2 & 836 & 119,4 \\
\hline Jumlah & 1 & 2 & 9 & 14 & 4 & 30 & \\
\hline
\end{tabular}

Sumber: Data terolah Tahun 2014

Tabel 6 menjelaskan bahwa responden dengan tingkat pendidikan tinggi (SMA/sederajat). memiliki rata-rata skor adopsi paling tinggi yaitu 119,4, diikuti responden dengan tingkat pendidikan SMP yaitu 112,4 dan tingkat pendidikan SD 95,31.. Hal ini menunjukkan adanya pengaruh pedidikan terhadap tingkat adopsi, selaras dengan pendapat Soetarjo dalam Azwardi (2001) yang menyatakan bahwa pendidikan seseorang pada umumnya mempengaruhi cara berpikirnya. Makin tinggi tingkat pendidikannya, makin dinamis sikapnya terhadap hal-hal baru.

Analisis statistik menggunakan program SPSS dengan analisis regresi linier sederhana dan dalam analisis statistik ini diasumsikan variabel yang lain tidak berpengaruh terhadap adopsi, diperoleh nilai konstanta (a) 71,280 dan nilai arah sebagai penentu ramalan (b) 4,113 sehingga persamaan regresi $\hat{Y}=71,280+4,113 \mathrm{X}$. Karena nilai koefisien (b) $=4,113$ (positif) maka model regresi bernilai positif atau searah, artinya jika nilai variabel tingkat pendidikan $(\mathrm{X})$ semakin tinggi maka nilai variabel tingkat adopsi (Y) semakin tinggi pula, selaras dengan pendapat Soetarjo dalam Azwardi (2001) yang menyatakan bahwa pendidikan seseorang pada umumnya mempengaruhi cara berpikirnya. Makin tinggi tingkat pendidikannya, makin dinamis sikapnya terhadap hal-hal baru. Nilai $P$ value Sig adalah 0,004 artinya karena nilai $P$ value Sig. kurang dari 0,05 maka dapat disimpulkan "terdapat pengaruh yang signifikan antara tingkat 
Abdul Farid, IGN, Mudita, Tri Pudjianto, Adopsi Inovasi Pemanfaatan Kotoran Ternak Sapi Untuk Pembuatan Pupuk Bokashi di Kelompoktani "Usaha Bersama” Desa Sekarmojo Kecamatan Purwosari Kabupaten Pasuruan

pendidikan (X) dengan tingkat adopsi (Y)", dan nilai koefisien korelasi adalah $\mathrm{R}=0,505$. Yang berarti hubungan antara tingkat pendidikan (X) dengan tingkat adopsi (Y) sedang. Koefisien Penentu (KP) atau ada yang menyebutnya koefisien Determinasi yang dirumuskan $\mathrm{KP}=\mathrm{R}^{2} \times 100 \%=(0,505)^{2} \times 100 \%$ diperoleh nilai $25,5 \%$ artinya tingkat pendidikan memberikan kontribusi terhadap tingkat adopsi sebesar $25,5 \%$ atau dapat disimpulkan tingkat adopsi dipengaruhi oleh umur sebesar $25,5 \%$ sedangkan sisanya dipengaruhi oleh faktor lain.

\section{Luas Usahatani}

Distribusi tingkat adopsi anggota kelompoktani terhadap pemanfaatan kotoran ternak sapi untuk pembuatan pupuk bokashi didasarkan pada luas usahatani responden disajikan pada table 7 .

Tabel 7. Distribusi Tingkat Adopsi Pemanfaatan Kotoran Ternak Sapi untuk Pembuatan Pupuk Bokashi Didasarkan Pada Luas Usahatani

\begin{tabular}{ccccccccc}
\hline $\begin{array}{c}\text { Luas } \\
\begin{array}{c}\text { Usaha } \\
\text { tani }\end{array}\end{array}$ & Kategori & \multicolumn{5}{c}{ Tingkat Adopsi } & $\begin{array}{c}\text { Skor } \\
\text { Adop } \\
\text { si }\end{array}$ & $\begin{array}{c}\text { Rata- } \\
\text { rata } \\
\text { Adops }\end{array}$ \\
\cline { 2 - 9 } $0,07-$ & Sempit & - & 2 & 8 & 10 & 1 & 2224 & 105,9 \\
$0,48-$ & Sedang & 1 & - & 2 & 2 & - & 449 & 89,8 \\
$0,89-$ & Luas & - & - & - & 1 & 3 & 502 & 125,5 \\
\hline \multicolumn{2}{r}{ Jumlah } & 1 & 2 & 10 & 13 & 4 & 30 & \\
\hline
\end{tabular}

Sumber: Data terolah Tahun 2014

Tabel 7 menunjukkan bahwa rata-rata skor adopsi paling tinggi diperoleh oleh responden dengan lahan luas dengan skor 125,5, kemudian responden dengan kepemilikan lahan sempit memperoleh rata-rata skor adopsi 105,9 dengan mayoritas pada tingkat adopsi mencoba, dan responden dengan kepemilikan lahan sedang paling banyak sudah mencapai tingkat adopsi mengevaluasi dan mencoba dengan rata-rata skor adopsi 89,8. Hal ini menunjukkan bahwa pada kategori kepemilikan lahan luas akan semakin baik tingkat adopsi responden terhadap pemanfaatan kotoran ternak sapi untuk pembuatan pupuk bokashi.

Analisis statistik menggunakan program SPSS dengan analisis regresi linier sederhana dan dalam analisis statistik ini diasumsikan variabel yang lain tidak berpengaruh terhadap adopsi, diperoleh nilai konstanta (a) 102,837 dan nilai arah sebagai penentu ramalan (b) 5,856 sehingga persamaan regresi $\hat{Y}=102,837+5,856$ X. Karena nilai koefisien $(b)=5,856$ (positif) maka model regresi bernilai positif atau searah, artinya jika nilai variabel Luas usahatani $(\mathrm{X})$ semakin tinggi maka nilai variabel tingkat adopsi (Y) semakin tinggi pula. Hal ini menunjukkan bahwa pada kategori kepemilikan lahan luas akan semakin baik tingkat adopsi responden terhadap pemanfaatan kotoran ternak sapi untuk pembuatan pupuk bokashi.

Nilai $P$ value Sig adalah 0,509 artinya karena nilai $P$ value Sig. lebih dari 0,05 maka dapat disimpulkan "tidak terdapat pengaruh yang signifikan antara luas lahan (X) dengan tingkat adopsi (Y). Kondisi ini tidak sejalan dengan pendapat Mardikanto (2002) yang menyatakan bahwa semakin luas usahatani biasanya semakin cepat mengadopsi, karena memiliki kemampuan ekonomi yang lebih baik. Sedangkan nilai koefisien korelasi adalah $\mathrm{R}=0,125$. Yang artinya hubungan antara luas usahatani $(\mathrm{X})$ dengan tingkat adopsi (Y) sangat rendah. Koefisien Penentu (KP) atau koefisien Determinasi yang dirumuskan $\mathrm{KP}=\mathrm{R}^{2} \times 100 \%=(0,125)^{2} \times 100 \%$ diperoleh nilai $1,56 \%$ 
Abdul Farid, IGN, Mudita, Tri Pudjianto, Adopsi Inovasi Pemanfaatan Kotoran Ternak Sapi Untuk Pembuatan Pupuk Bokashi di Kelompoktani "Usaha Bersama” Desa Sekarmojo Kecamatan Purwosari Kabupaten Pasuruan

artinya luas usahatani memberikan kontribusi terhadap tingkat adopsi hanya sebesar $1,56 \%$ atau bisa dikatakan tidak mempengaruhi tingkat adopsi pemanfaatan kotoran ternak sapi untuk pembuatan pupuk bokashi.

\section{Penglaman Berusahatani}

Pengalaman seseorang akan mempengaruhi cepat lambatnya adopsi terhadap inovasi baru. Hal ini ditunjukkan dengan hasil yang diperoleh setelah variabel pengalaman berusahatani diregresikan dengan tingkat adopsi. Distribusi tingkat adopsi anggota kelompoktani terhadap pemanfaatan kotoran ternak sapi untuk pembuatan pupuk bokashi didasarkan pada pengalaman berusahatani responden disajikan pada Tabel 4.

Tabel 8. Distribusi Tingkat Adopsi Pemanfaatan Kotoran Ternak Sapi Untuk Pembuatan Pupuk Bokashi Didasarkan Pada Pengalaman Berusahatani

\begin{tabular}{ccccccccc}
\hline $\begin{array}{c}\text { Pengalaman } \\
\begin{array}{c}\text { Berusahatan } \\
\text { i (tahun) }\end{array}\end{array}$ & Kategori & Sadar & Minat & Evaluasi & Mencoba & Menerapkan & $\begin{array}{c}\text { Skor } \\
\text { Adopsi }\end{array}$ & $\begin{array}{c}\text { Rata- } \\
\text { rata } \\
\text { Adopsi }\end{array}$ \\
\hline $4-14$ & Baru & - & - & 1 & 4 & 2 & 826 & 118 \\
$15-25$ & Sedan & - & - & 3 & 6 & 2 & 872 & 109 \\
$26-36$ & Lama & 1 & 2 & 6 & 3 & - & 1501 & 100,1 \\
\hline \multicolumn{2}{l}{ Jumlah } & 1 & 2 & 10 & 13 & 4 & 30 & \\
\hline
\end{tabular}

Sumber: Data terolah Tahun 201

Tabel 8 menjelaskan bahwa responden dengan kategori pengalaman berusahatani baru memiliki rata-rata skor adopsi yang paling tinggi yaitu 118, dengan mayoritas mencapai tahap adopsi mencoba, diikuti responden dengan pengalaman berusahatani sedang dengan rata-rata skor 109 dan mayoritas responden mencapai tahap adopsi mencoba. Sedangkan responden dengan pengalaman berusahatani lama mempunyai ratarata skor 100,1 yang mayoritas responden mencapai tahap mengevaluasi. Hal ini membuktikan bahwa pengalaman bertani yang lebih lama tidak menjamin akan lebih cepat dalam mengadopsi suatu inovasi. Berbeda dengan pendapat Mosher (1977) dalam Kusumahadi (1989) yang menyatakan lama usaha adalah pengalaman berharga yang dapat diambil manfaatnya sehingga dapat membantu petani dalam mengembangkan usaha taninya. Hal ini dikarenakan adanya ketergantungan responden terhadap pertanian anorganik, sehingga jika ada teknologi tentang pertanian organik (seperti penggunaan pupuk organik),perlu proses untuk menerima teknologi tersebut, sedangkan waktu kajian sangat singkat.

Analisis statistik menggunakan program SPSS dengan analisis regresi linier sederhana dan dalam analisis statistik ini diasumsikan variabel yang lain tidak berpengaruh terhadap adopsi, diperoleh nilaikonstanta (a) 128,564 dan nilai arah sebagai penentu ramalan (b) $-1,152$ sehingga persamaan regresi $\hat{Y}=128,564+(-1,152) X$. Karena nilai koefisien $(b)=-1,152$ (negaitif) maka model regresi bernilai negatif, artinya jika nilai variabel pengalaman berusahatani $(X)$ semakin tinggi maka nilai variabel tingkat adopsi (Y) semakin rendah.. Nilai $P$ value Sig adalah 0,000 artinya karena nilai $P$ value Sig. lebih kecil dari 0,05 maka dapat disimpulkan terdapat pengaruh yang signifikan antara pengalaman bertani $(\mathrm{X})$ dengan tingkat adopsi $(\mathrm{Y})$. Sedangkan nilai koefisien korelasi adalah $\mathrm{R}=0,627$, artinya hubungan antara pengalaman bertani $(\mathrm{X})$ 
Abdul Farid, IGN, Mudita, Tri Pudjianto, Adopsi Inovasi Pemanfaatan Kotoran Ternak Sapi Untuk Pembuatan Pupuk Bokashi di Kelompoktani "Usaha Bersama” Desa Sekarmojo Kecamatan Purwosari Kabupaten Pasuruan

dengan tingkat adopsi (Y) kuat. Koefisien Penentu (KP) atau koefisien Determinasi yang dirumuskan $\mathrm{KP}=\mathrm{R}^{2} \times 100 \%=(0,627)^{2} \times 100 \%$ diperoleh nilai $39,31 \%$ artinya luas usahatani memberikan kontribusi terhadap tingkat adopsi sebesar $39,31 \%$ atau dapat disimpulkan tingkat adopsi dipengaruhi oleh pengalaman bertani sebesar 39,31\% sedangkan sisanya dipengaruhi oleh faktor lain.

\section{Pelaksanaan Penyuluhan}

\section{Penetapan Rancangan Penyuluhan}

Rancangan penyuluhan ditetapkan dengan berpedoman pada UU No. 16 Tahun 2006 tentang SP3K dimana penyuluhan harus sesuai dengan kebutuhan dan kondisi sasaran. Rancangan penyuluhan dengan judul Pemanfaatan Kotoran Ternak Sapi untuk Pembuatan Pupuk Bokashi ditetapkan atas dasar hasil survey tentang penggunaan pupuk bokasi dari kotoran sapi di Kelompoktani Usaha Bersama Desa Sekarmojo. Adapun hasil tabulasi dan analisis regresi sederhana menunjukkan faktor-faktor yang mempengaruhi tingkat adopsi petani terhadap inovasi pemanfaatan kotoran ternak sapi untuk pembuatan pupuk bokashi adalah variabel umur, tingkat pendidikan, dan pengalaman berusahatani, sehingga dalam penetapan rancangan penyuluhan dilakukan dengan memperhatikan faktor-faktor tersebut.

Dengan demikian dalam penetapan rancangan penyuluhan dibuat secara sistematis dan dapat diimplementasikan. Adapun penetapan rancangan penyuluhan meliputi:

\section{Tujuan}

Tujuan yang diharapkan dalam pelaksanaan penyuluhan adalah adanya perubahan tingkat pengetahuan petani tentang pembuatan pupuk bokashi dari kotoran sapi. Dan kedepannya terjadi keseimbangan antara penggunaan pupuk organik dan pupuk kimia sehingga tingkat kesuburan tanah lambat laun akan meningkat.

\section{Sasaran}

Sasaran penyuluhan adalah seluruh anggota Kelompoktani Usaha Bersama Desa Sekarmojo Kecamatan Purwosari. Sedangkan 30 orang petani telah dipilih sebagai sampel dalam kegiatan penelitian, hal ini ditetapkan guna memudahkan dalam melakukan kegiatan penelitian.

\section{Metode}

Metode dan teknik penyuluhan yang digunakan adalah ceramah, diskusi dan demonstrasi cara, dengan pendekatan partisipatif melalui anggota kelompoktani Demontrasi cara bertujuan untuk meyakinkan orang bahwa cara kerja yang dianjurkan tentang pembuatan pupuk bokashi mudah atau praktis dilaksanakan. Demontrasi cara bermanfaat untuk mengajarkan keterampilan yang efektif kepada petani, merangsang minat dan merangsang kegiatan serta memiliki efek publisitas yang luas. Namun apabila demontrasi cara berjalan tidak baik, akan berakibat negatif terhadap perkembangan penyuluhan di lokasi tersebut, oleh karena itu penulis memaksimalkan keberhasilan dalam demontrasi cara.

\section{Media}

Media yang digunakan dalam kegiatan penyuluhan adalah folder dan benda sesungguhnya. Folder digunakan pada saat pertemuan kelompok maupun perorangan dengan pertimbangan dapat disimpan, dibawa dengan mudah dan dapat digunakan kapan 
Abdul Farid, IGN, Mudita, Tri Pudjianto, Adopsi Inovasi Pemanfaatan Kotoran Ternak Sapi Untuk Pembuatan Pupuk Bokashi di Kelompoktani "Usaha Bersama” Desa Sekarmojo Kecamatan Purwosari Kabupaten Pasuruan

saja. Benda sesungguhnya dalam hal ini adalah semua bahan yang digunakan pada saat penyuluhan dan demonstrasi cara.

\section{Pelaksanaan Kegiatan Penyuluhan}

Penyuluhan dengan pendekatan individu dilaksanakan tanggal 9 Juni sampai 13 Juni 2014, sedangkan kegiatan penyuluhan dengan pertemuan kelompok dilaksanakan pada tanggal 19 Juni 2014.

Tempat pertemuan kelompok dilakukan di rumah Ketua Kelompoktani Usaha Bersama di Dusun Garman Desa Sekarmojo Kecamatan Purwosari Kabupaten Pasuruan.

\section{Evaluasi Penyuluhan}

Hasil analisa efektifitas peningkatan pengetahuan dapat diketahui melalui perhitungan sebagai berikut:

$$
\begin{aligned}
\text { Efektivitas Peningkatan Pengetahuan }= & \frac{P s-\operatorname{Pr}}{(N .5 . Q)-\operatorname{Pr}} \times 100 \% \\
& =\frac{2324-1320}{(30.5 .20)-1320} \times 100 \% \\
& =59,76 \%
\end{aligned}
$$

$$
\begin{aligned}
\text { Efektifitas Program } & =\frac{P s}{N 5 Q} \times 100 \% \\
& =\frac{2324}{30.5 .20} \times 100 \% \\
& =77,5 \%
\end{aligned}
$$

Efektifitas peningkatan pengetahuan sebesar 59,76 \% dikatagorikan cukup efektif dan efektifitas program 77,5\% dikategorikan efektif. Hasil yang diperoleh cukup efektif ini dikarenakan materi, media, metode dan teknik penyuluhan yang digunakan sangat relevan dengan responden dan keaktifan dari responden.

\section{KESIMPULAN}

1. Tingkat adopsi pemanfaatan kotoran ternak sapi untuk pembuatan pupuk bokashi di Kelompoktani Usaha Bersama Desa Sekarmojo masih rendah, dari karakteristik responden yang diamati yaitu umur, tingkat pendidikan, luas usaha tani dan pengalaman bertani, masing-masing menunjukkan jumlah responden yang mencapai tahap menerapkan hanya 4 responden dari 30 responden sampel.

1. Dengan taraf signifikan $(\alpha) 0,05$, umur berpengaruh yang signifikan terhadap adopsi pemanfaatan kotoran ternak sapi untuk pembuatan pupuk bokashi dengan nilai signifikansi 0,008, namun mempunyai arah ramalan negatif. Tingkat pendidikan berpengaruh positif yang signifikan terhadap tingkat adopsi dengan nilai signifikansi 0,004. Luas usahatani tidak berpengaruh signifikan terhadap tingkat adopsi dengan nilai signifikansi 0,509. Sedangkan pengalaman berusahatani berpengaruh yang signifikan 
Abdul Farid, IGN, Mudita, Tri Pudjianto, Adopsi Inovasi Pemanfaatan Kotoran Ternak Sapi Untuk Pembuatan Pupuk Bokashi di Kelompoktani "Usaha Bersama” Desa Sekarmojo Kecamatan Purwosari Kabupaten Pasuruan

terhadap tingkat adopsi pemanfaatan kotoran ternak sapi untuk pembuatan pupuk bokashi dengan nilai signifikansi 0,000 namun mempunyai arah ramalan negatif.

Penyuluhan tentang pemanfaatan kotoran ternak sapi untuk pembuatan pupuk bokashi menggunakan metode dan teknik ceramah, diskusi, demonstrasi cara. Media yang digunakan folder dan benda sesungguhnya. Berdasarkan evaluasi penyuluhan dapat diketahui efektifitas peningkatan pengetahuan sebesar 59,76\% dikategorikan cukup efektif, dan efektifitas program sebesar 77,5\% dikategorikan efektif.

\section{DAFTAR PUSTAKA}

Azwar, 2009. Sikap Manusia, Teori dan Pengukurannya, Yogyakarta: Pustaka Pelajar Offset.

Azwardi, D., 2001. Kajian Tingkat Teknologi Pembenihan Ikan Mas (Cyprinus Carpio) pada Sentra Benih Ikan di Sumatera Barat. Thesis, Pasca Sarjana UGM. Yogyakarta.

Djuarnani, N, Kriatian, dan Setiawan, B.S. 2005. Cara Cepat Membuat Kompos. Agromedia. Bogor.

Ginting, E. 2005. Pedoman Penyelenggaraan Penyuluhan Pertanian Dalam Era Otonomi Daerah. Badan Pengembangan Sumberdaya Manusia Pertanian. Jakarta.

Kusumahadi, D. 1989. Beberapa faktor sosial Ekonomi yang mempengaruhi tingkat adopsi Panca usaha Peternakan sapi perah. Tesis. Universitas Gajah Mada. Program KPK UGM-UNIBRAW. Malang.

Mardikanto, T. 1993. Penyuluhan Pembangunan Pertanian. Sebelas Maret University Press. Surakarta.

Nasir, 2008. Pengaruh Penggunaan Pupuk Bokashi pada Pertumbuhan dan Produksi Tanaman Padi, Palawija dan Sayuran. (http/www.dispertanakpandeglang.co.id/, diakses 3 Pebruari 2014).

Padmowihardjo S, 2001. Evaluasi Penyuluhan Pertanian. Universitas Terbuka. Jakarta.

Riduwan. 2012. Belajar Mudah Penelitian untuk Guru Karyawan dan Peneliti Pemula. Alfabeta. Bandung.

Samsudin, U.S. 1982. Dasar-Dasar Penyuluhan dan Modernisasi Pertanian. Binacipta. Bandung.

Setiana, L. 2005. Teknik Penyuluhan dan Pemberdayaan masyarakat. Ghalia Indonesia. Bogor.

Setiawan, A, 2007. Memanfaatkan Kotoran Ternak. Agrotekno. Jakarta.

Soedarmanto. 1989. Diktat Dasar-dasar Dan Pengelolaan Penyuluhan Pertanian. Universitas Brawijaya. Malang. 
Abdul Farid, IGN, Mudita, Tri Pudjianto, Adopsi Inovasi Pemanfaatan Kotoran Ternak Sapi Untuk Pembuatan

Pupuk Bokashi di Kelompoktani "Usaha Bersama” Desa Sekarmojo Kecamatan Purwosari Kabupaten

Pasuruan

Soekartawi. 2005. Prinsip Dasar Komunikasi Pertanian. Universitas Indonesia.

Jakarta.

Sugiyono. 2007.Statistika untuk Penelitian. Alfabeta. Bandung.

Tjiptoherijanto. 2001. Proyeksi Penduduk, Angkatan Kerja, Tenaga Kerja dan Peran Serikat Pekerja dalam Peningkatan Kesejahteraan. Majalah Perencanaan Pembangunan, Edisi 23 Th. 2001. (www.bappenas.go.id/files/, diakses 11 Juli 2014).

Undang-Undang Sistem Penyuluhan Pertanian, Perikanan dan Kehutanan (SP3K) No 16 Tahun 2006. Departemen Pertanian. Jakarta.

Van den Ban, A.W dan Hawkins, H.S. 1999. Penyuluhan Pertanian. Kanisius: Yogyakarta.

Wahyuti, U. 2003. Pedoman Pemilihan Metode Penyuluhan Pertanian. STPP Malang Press. Malang.

Wijaya, K. A. 2008 : Nutrisi Tanaman. Prestasi Pustaka Publisher. Jakarta

Yuliarti, N. 2009. 1001 Cara Menghasilkan Pupuk Organik. Lily Publisher. Yogyakarta. 